\title{
Purification and physicochemical characterisation of Aspergillus niger USM F4 $\beta$-mannanase
}

\author{
Ab Rashid Syarifah ${ }^{1,2 \star}$, Ibrahim Darah ${ }^{1}$, Che Omar Ibrahim ${ }^{3}$, Hassan Ramli ${ }^{4}$ and Woei Yenn Tong ${ }^{2}$ \\ ${ }^{1}$ Industrial Biotechnology Research Laboratory (IBRL), School of Biological Sciences, Universiti Sains Malaysia, 11800 \\ Minden, Penang Malaysia. \\ ${ }^{2}$ Universiti Kuala Lumpur, Malaysian Institute of Chemical and Bioengineering Technology, Lot 1988 Kawasan \\ Perindustrian Bandar Vendor, Taboh Naning, 78000 Alor Gajah, Melaka, Malaysia. \\ ${ }^{3}$ Universiti Malaysia Kelantan, Kota Campus, Locked bag 36, 16100 Pengkalan Chepa, Kelantan, Malaysia. \\ ${ }^{4}$ Dinas Penternakan Aceh jl Dr Mr Mohd Hassan, 23117 Banda Aceh, Indonesia. \\ Email: syarifahabrashid@unikl.edu.my
}

Received 16 January 2020; Received in revised form 13 March 2020; Accepted 24 April 2020

\begin{abstract}
Aims: This present study focused on purification of fungal $\beta$-mannanase produced by Aspergillus niger USM F4 and also physicochemical characterisation of the purified enzyme.

Methodology and results: The purified $\beta$-mannanase with a molecular mass of $\sim 47.4 \mathrm{kDa}$ was demonstrated on SDSPAGE gel. The enzyme signified a purification degree of 4 -fold, with final specific activity of $196.42 \mathrm{U} / \mathrm{mg}$. It reached an optimum catalytic activity at $\mathrm{pH} 4.0$ and $60^{\circ} \mathrm{C}$. The thermal stability of the enzyme was up to $70^{\circ} \mathrm{C}$ and maintained the $50 \%$ activity after $30 \mathrm{~min}$ at $80^{\circ} \mathrm{C}$. Meanwhile, the $\mathrm{pH}$ stability was in the range of $\mathrm{pH} 3.0-9.0$ and a $30 \mathrm{~min}$ half-life at $\mathrm{pH}$ 10.0. All chemical substances manifested an inhibitory effect on purified $\beta$-mannanase, with SDS $(28.16 \pm 0.05 \%$ residual activity) as the strongest inhibitor, followed by cupric ion $\left(\mathrm{Cu}^{2+}\right)(49.51 \pm 0.09 \%$ residual activity). As a whole, the enzyme displayed a substrate specificity in the order of locust bean gum (LBG) > carboxymethylcellulose > soluble starch > xylan from oat spelt $>$ a-cellulose. Its preference for LBG has generated the $K_{m}$ and $V_{\max }$ values of $0.20 \mathrm{mg} / \mathrm{mL}$ and $9.82 \mathrm{U} / \mathrm{mL}$, respectively.

Conclusion, significance and impact of study: The outcomes of our study offer potential for use at industrial scales, particularly in the oligosaccharides production that involve acid-related activity, wide-ranging temperature and $\mathrm{pH}$ stability.
\end{abstract}

Keywords: Mannanase, palm kernel cake, physicochemical characterisation, protein purification

\section{INTRODUCTION}

Indonesia and Malaysia are recognised as the global supreme palm oil producers other than Nigeria, Colombia, and Thailand. In general, the palm oil is originated from the pressing process of fresh fruits and seeds of oil palm which later produced the residual wastes known as empty fruit bunch (EFB) and palm kernel cake (PKC). Malaysia spawned a massive amount of PKC with 2.59 million tonnes of production in 2018 (MPOB, 2019). The statistic has indirectly made PKC resources as cheap and accessible leftover. According to the nutrients profile, PKC owns a relatively high protein content (14-16\%), essential amino acids, minerals (Marini et al., 2005), and vitamin $\mathrm{E}$ (Krishnaiah et al., 2012). PKC is a latent source of mannan oligosaccharide since its crude fibre impregnated hemicelluloses with superficially predominated by $57.8 \%$ mannan, $11.6 \%$ cellulose, and $3.7 \%$ xylan (Abd-Aziz et al., 2009; Nurhayati et al., 2018). Hence, PKC can stimulate the production of mannan-degrading enzymes by analysing the end-product of reducing sugar such as mannose (Syarifah et al., 2012). Other than monomer mannose, the execution of enzymatic mannan conversion will also tag along a small amount of galactose and cellulose (Illuyemi et al., 2006).

Fungi species including Aspergillus sp., Trichoderma sp., Penicillium sp., Sclerotium sp., Bispora sp., and Scopulariopsis sp. are identified as potential producers for fungal mannan-degrading enzymes (Regalado et al., 2000; Mudau and Setati, 2008; Luo et al., 2009; Blibech et al., 2011; Wu et al., 2011). Of that, Aspergillus is the most actively reported fungal genus due to the high yield of extracellular enzymes production and its natural characteristic in degrading a plethora of organic substances. The acclimatising capability of the genus Aspergillus, especially in solid-state fermentation (SSF) 
system, is irrefutable because the fungi grow via polarised elongation using the hyphal tip (Takeshita, 2016). This tip can deeply penetrate the solid substrate, prior to colonisation and nutrients absorption. As a surplus, most of the species can endure an extreme temperature, low water activity and high osmosis pressure. These characteristics have provided a competence benefit for the genus Aspergillus against other natural microflora in adapting the SSF system. SSF is a heterogeneous bioprocess of solid, liquid and gaseous phases (Costa et al., 2018).

$\beta$-mannanase (E.C. 3.2.1.78) hydrolyses the $\beta-1,4$ linkages in mannan backbone and sequentially releasing mannooligosaccharides. The biological and chemical properties of this enzyme have been employed for over extensive years and vastly engaged with agriculture including animal feed, fruit ripening, pulp bleaching, and detergent (Carrington et al., 2002; Benech et al., 2007; Srivastava and Kapoor, 2013; Tewoldebrhan et al., 2017). These events have driven to the purification development of fungal and bacterial enzymes. Thus far, pure $\beta$ mannanase can be produced by fungi and bacteria, with a tendency for acidic to neutral $\mathrm{pH}$ conditions as well as a range of moderate thermophilic temperatures (Naganagouda et al., 2009; El-Sharouny et al., 2015 Cheng et al., 2016). In this study, we discovered the efficient physicochemical properties of $A$. niger $\beta$ mannanase through its purification development and enzymatic characterisation.

\section{MATERIALS AND METHODS}

\section{Chemicals}

All chemicals were procured from Sigma-Aldrich (USA), Hi-Media Lab. LTD (India) and Fluka (USA). Solid substrate or PKC in the SSF system was provided by a local palm oil mill factory located at Seberang Perai district area, Pulau Pinang, Malaysia.

\section{Filamentous fungus and solid-state fermentation system}

An isolate identified as $A$. niger USM F4 was originated from fungal culture stock of Industrial Biotechnology Research Laboratory (IBRL), Universiti Sains Malaysia, Pulau Pinang, Malaysia. The fermentation cycle was performed in $250 \mathrm{~mL}$ flask according to the method of Syarifah (2010). A complete SSF system comprised $80 \%$

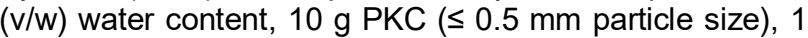
$\times 10^{7}$ spore $/ \mathrm{mL}$ fungal spore suspension, $2 \%(\mathrm{w} / \mathrm{w})$ molasses and $2 \%(\mathrm{w} / \mathrm{w})$ ammonium nitrate $\left(\mathrm{NH}_{4} \mathrm{NO}_{3}\right)$. All flasks were incubated at $30 \pm 2{ }^{\circ} \mathrm{C}$ and harvested after 5 days of cultivation period.

\section{$\beta$-mannanase extraction and assay}

Fermented PKC was extracted using Tween 80 and filtered through the Whatman filter paper No.1. Then, the crude enzyme filtrate $(0.5 \mathrm{~mL})$ was mixed with $0.5 \%(\mathrm{w} / \mathrm{v})$ locust bean gum (LBG), which was pre-dissolved in 50 $\mathrm{mM}$ citric acid-trisodium citrate buffer $\mathrm{pH}$ 4.0. Next, the test tubes containing the enzyme-substrate mixture were incubated at $60{ }^{\circ} \mathrm{C}$ for $30 \mathrm{~min}$. Dinitrosalicylic acid (1.5 $\mathrm{mL}$ ) was added into the mixture and boiled for $5 \mathrm{~min}$. The enzyme activity was verified at $575 \mathrm{~nm}$ by using spectrophotometer (Lin and Chen, 2004). One unit of $\beta$ mannanase activity was described as the sum of enzyme needed to release one $\mu \mathrm{mol}$ of mannose equivalents per minute according to the assay conditions.

\section{Protein content measurement}

Protein content was measured spectrophotometrically at $280 \mathrm{~nm}$ and bovine serum albumin was set as a standard (Lowry et al., 1951).

\section{Purification of $\boldsymbol{A}$. niger USM F4 $\beta$-mannanase}

The enzyme was purified through three-step purification processes: ultrafiltration, molecular sieve chromatography and anion exchange chromatography. Initially, a total of $100 \mathrm{~mL}$ of crude enzyme filtrate was submitted to Vivaflow Masterflex C/S (Cole Parmer, USA) equipped with a 10 $\mathrm{kDa}$ cut-off membrane threshold, before molecular sieve chromatographic step. Then, the sample was further purified on a Superdex $75 \mathrm{gel}$ column size of $30 \times 1 \mathrm{~cm}$ which previously equilibrated with citric acid-trisodium citrate buffer $(50 \mathrm{mM}, \mathrm{pH} 4.0)$. Elution was attained at a rate of $0.12 \mathrm{~mL} / \mathrm{min}$. The fractions with high enzyme activity were pooled and proceeded with anion exchange chromatography. The pooled samples were further filtrated using Amicon Ultra-15 (3 kDa cut-off membrane; Millipore, USA). Then, the filtrates were streamed to Qsepharose fast flow column and eluted with $50 \mathrm{mM}$ citric acid-trisodium citrate buffer $(\mathrm{pH} 5.0)$ containing $0.8 \mathrm{M}$ sodium hydroxide. At a flow rate of $0.2 \mathrm{~mL} / \mathrm{min}$, the fractions were collected and further analysed for the $\beta$ mannanase activity $\left(A_{575}\right)$ and total protein content $\left(A_{280}\right)$.

\section{Electrophoresis and $\beta$-mannanase molecular mass}

The purity of chromatographic enzyme and its molecular mass were verified through electrophoretic separation in SDS-PAGE (Bio-Rad, USA) (Laemmli, 1970). Under nondenaturing conditions of $12.5 \%$ separating gel and $2.5 \%$ stacking gel, all samples including the crude and purified enzyme were loaded into the gel lane and compared against a standard marker (low molecular weight protein marker, Pharmacia, Sweden). The electrophoresis process was performed approximately $3 \mathrm{~h}$ in a $1 \times$ solution of running buffer at $4{ }^{\circ} \mathrm{C}$ using a constant voltage of 80 volts. For protein bands visualisation, SDS-PAGE gel was stained with the silver nitrate (Bollag et al., 1996). The molecular mass of the purified $\beta$-mannanase was estimated according to the plot from a pair-wise combination of the molecular mass of the standard and the relative mobility $(\mathrm{Rf})$. The range of protein sizes varied from $18.4 \mathrm{kDa}$ ( $\beta$-lactoglobulin) to $116 \mathrm{kDa}(\beta-$ galactosidase). 


\section{Physicochemical characterisation of $\beta$-Mannanase}

The influence of $\mathrm{pH}$ conditions on enzyme activity and stability

The ideal $\mathrm{pH}$ of enzyme activity was analysed by introducing the purified $\beta$-mannanase to acid-trisodium citrate buffer ( $\mathrm{pH} 3.0,4.0$ and 5.0), phosphate buffer $(\mathrm{pH}$ 6.0 and 7.0), Tris- $\mathrm{HCl}$ buffer (pH 8.0 and 9.0) and glycine$\mathrm{NaOH}(\mathrm{pH} 10.0)$. Each buffer was set at $50 \mathrm{mM}$. The enzyme was mixed with $0.5 \%(\mathrm{w} / \mathrm{v})$ LBG which was predissolved in different buffers, prior to the standard assay procedure. A few of $\mathrm{pH}$ conditions that exhibited high enzyme activity were selected for the stability test. Without LBG, the purified enzyme was pre-incubated with the $\mathrm{pH}$ buffers for $30 \mathrm{~min}$, with $5 \mathrm{~min}$ intervals. Then, the residual enzyme activity was promptly analysed according to the enzyme assay.

The influence of temperature conditions on enzyme activity and stability

The thermal effect on activity was done by introducing the purified enzyme to temperatures ranging from 50 to $80^{\circ} \mathrm{C}$ for $30 \mathrm{~min}$ in citric acid-trisodium citrate buffer $(50 \mathrm{mM}, \mathrm{pH}$ 4.0). After that, the stability test was done by preincubating the enzyme (without LBG) at different temperatures for $30 \mathrm{~min}$. For every $5 \mathrm{~min}$, the remaining residual activity was immediately approximated by the enzyme assay.

The influence of chemical substances on purified $\beta$ mannanase

Purified enzyme liquid was incubated for $30 \mathrm{~min}$ at $60^{\circ} \mathrm{C}$ in the presence of $1.0 \mathrm{mM} 2$-mercaptoethanol, sodium dodecyl sulphate (SDS), ethylenediaminetetraacetic acid
(EDTA), strontium chloride $\left(\mathrm{SrCl}_{2}\right)$, potassium chloride (KCl), zinc chloride $\left(\mathrm{ZnCl}_{2}\right)$, iron (III) chloride $\left(\mathrm{FeCl}_{3}\right)$, zinc sulphate $\left(\mathrm{ZnSO}_{4}\right)$, copper (II) sulphate $\left(\mathrm{CuSO}_{4}\right)$, sodium chloride $(\mathrm{NaCl})$, calcium chloride $\left(\mathrm{CaCl}_{2}\right)$, manganese (II) chloride $\left(\mathrm{MnCl}_{2}\right)$, aluminium chloride $\left(\mathrm{AlCl}_{3}\right)$, and magnesium chloride $\left(\mathrm{MgCl}_{2}\right)$. The purified enzyme (without any additive) was set as a control in this experimental study and the relative activity of $\beta$ mannanase was measured under the optimised assay conditions (LBG, pH 4.0 and temperature of $60^{\circ} \mathrm{C}$ ).

\section{Substrate specificity and kinetic study}

The specificity of $\beta$-mannanase was evaluated by assaying the activity against $0.5 \% \quad(\mathrm{w} / \mathrm{v})$ LBG, carboxymethyl cellulose, soluble starch, a-cellulose, and xylan from oat spelts, The substrate that gave the best enzyme activity was analysed at concentrations of 0.25 to $1.5 \%(\mathrm{w} / \mathrm{v})$ and was determined under the optimised assay conditions. To scrutinise the preference of the purified enzyme on the selected substrate, the $K_{m}$ and $\mathrm{V}_{\max }$ were evaluated from Lineweaver-Burk plots (Lineweaver and Burk, 1934).

\section{RESULTS AND DISCUSSION}

Cultivation of $A$. niger USM F4 with PKC as a mannanbased substrate has successfully generated an extracellular $\beta$-mannanase. The design of isolation and purification of the enzyme is summarised in Table 1. The first ultrafiltration step using Vivaflow Masterflex $\mathrm{C} / \mathrm{S}$ has eliminated $\leq 10 \mathrm{kDa}$ nano-particles protein, while the lower protein cut-off $(\leq 3 \mathrm{kDa})$ was removed by Amicon Ultra 15. The efficiency of both processes was proven since the multiple purification reached 1.42 -fold and 2.58fold, respectively.

Table 1: Purification steps of the the $\beta$-mannanase from Aspergillus niger USM F4.

\begin{tabular}{|c|c|c|c|c|c|c|c|}
\hline $\begin{array}{l}\text { Purification } \\
\text { step }\end{array}$ & $\begin{array}{l}\text { Activity } \\
\text { (U/mL) }\end{array}$ & $\begin{array}{c}\text { Total } \\
\text { volume } \\
\text { (mL) }\end{array}$ & $\begin{array}{l}\beta \text {-mannanase } \\
\text { activity } \\
\text { (U) }\end{array}$ & $\begin{array}{c}\text { Total protein } \\
\text { (mg) }\end{array}$ & $\begin{array}{l}\text { Specific activity } \\
(\mathrm{U} / \mathrm{mg})\end{array}$ & $\begin{array}{l}\text { Yield } \\
(\%)\end{array}$ & $\begin{array}{l}\text { Purification } \\
\text { (fold) }\end{array}$ \\
\hline $\begin{array}{l}\text { Crude culture } \\
\text { filtrate }\end{array}$ & 29.73 & 100 & 2973 & 60.5 & 49.14 & 100 & 1 \\
\hline $\begin{array}{l}\text { Ultrafiltration } \\
\text { using Vivaflow } \\
\text { Masterflex C/S }\end{array}$ & 138.89 & 20 & 2777.8 & 39.67 & 70.02 & 93.43 & 1.42 \\
\hline Superdex 75 & 72.42 & 2 & 144.84 & 1.44 & 100.58 & 4.87 & 2.05 \\
\hline $\begin{array}{l}\text { Ultrafiltration } \\
\text { using Amicon } \\
\text { Ultra } 15\end{array}$ & 26.01 & 2 & 52.02 & 0.41 & 126.88 & 1.75 & 2.58 \\
\hline $\begin{array}{l}\text { Q-sepharose } \\
\text { fast flow }\end{array}$ & 8.25 & 2 & 16.5 & 0.084 & 196.42 & 0.55 & 4 \\
\hline
\end{tabular}


According to the elution of the Superdex 75 column, fractions 7 to 9 indicated an ascending pattern of $\beta$ mannanase activity together with the first peak protein (Figure 1). Fraction 8 was recorded as the highest enzyme activity specifically $72.42 \mathrm{U} / \mathrm{mL}$ and $0.72 \mathrm{mg} / \mathrm{mL}$ protein content. The same graph also showed the second and third peak proteins between fractions 10 to 19 . $\beta$ mannanase was further purified to homogeneity via anion exchanger Q-sepharose fast flow (Figure 2). The enzyme activity gradually increased from fractions 11 to 13 , with fraction 12 recorded the highest activity. This event represented $196.42 \mathrm{U} / \mathrm{mg}$ final specific activity, 0.55\% recovery yield and 4-fold purification factor of $\beta$ mannanase. SDS-PAGE analysis revealed a single band of $\beta$-mannanase with the molecular mass of $\sim 47.4 \mathrm{kDa}$ (Figure 3).

The specific activity of fungal $\beta$-mannanase was reported approximately from 19.09 to $27864.6 \mathrm{U} / \mathrm{mg}$ (Mudau and Setati, 2008; Adesina et al., 2013). The recovery yields varied from 0.53 to $71.2 \%$ which was in consensus with studies by Puchart et al. (2004) and $\mathrm{Kim}$ et al. (2011). In most purification schemes, there are one to five general steps of microbial $\beta$-mannanase purification and each step can affect the purification fold. The degree of purification which involved one or two purification steps can range from 1.14 to 64.73-fold (Mudau and Setati, 2008; Harnpicharnchai et al., 2016). In comparison to its counterpart, the extension steps could generate a much higher fold approximately 13.6 to 810 fold (Zakaria et al., 1998; Naganagouda et al., 2009; ElSharouny et al., 2015). The purification fold in our study was much lower than the previously reported findings, albeit we engaged with four purification steps. It is widely known that fungal enzymes are more tedious to be purified. The ultrafiltration process may also contribute to the low purification fold. The concept for protein filtration or concentration using ultrafiltration is based on pressurising the liquid through a setting membrane while maintaining the protein of interest. However, this process could disassemble the protein arrangement and leads to its denaturation. This study supported previous findings of which the molecular mass of purified mannanase from the genus Aspergillus was in the range of $40-110 \mathrm{kDa}$ (Ademark et al., 1998; Regalado et al., 2000; Puchart et al., 2004; Naganagouda et al., 2009; Wu et al., 2011).

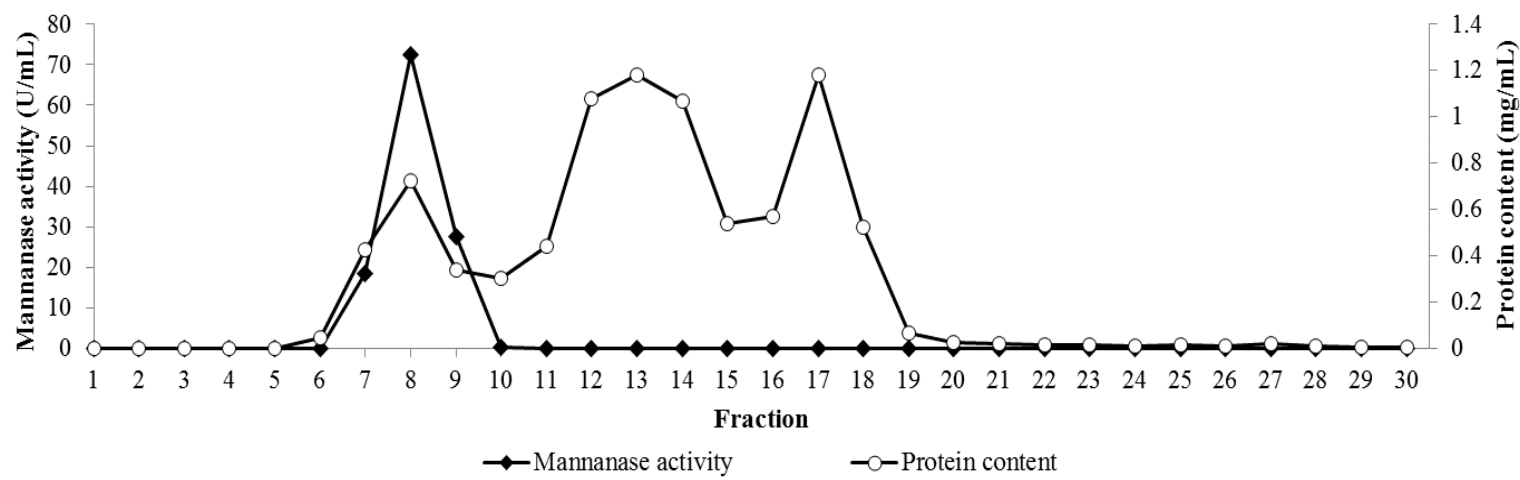

Figure 1: Purification of $\beta$-mannanase using Superdex 75 column chromatography with $50 \mathrm{mM}$ citric acid-trisodium citrate buffer $(\mathrm{pH} 4.0)$.

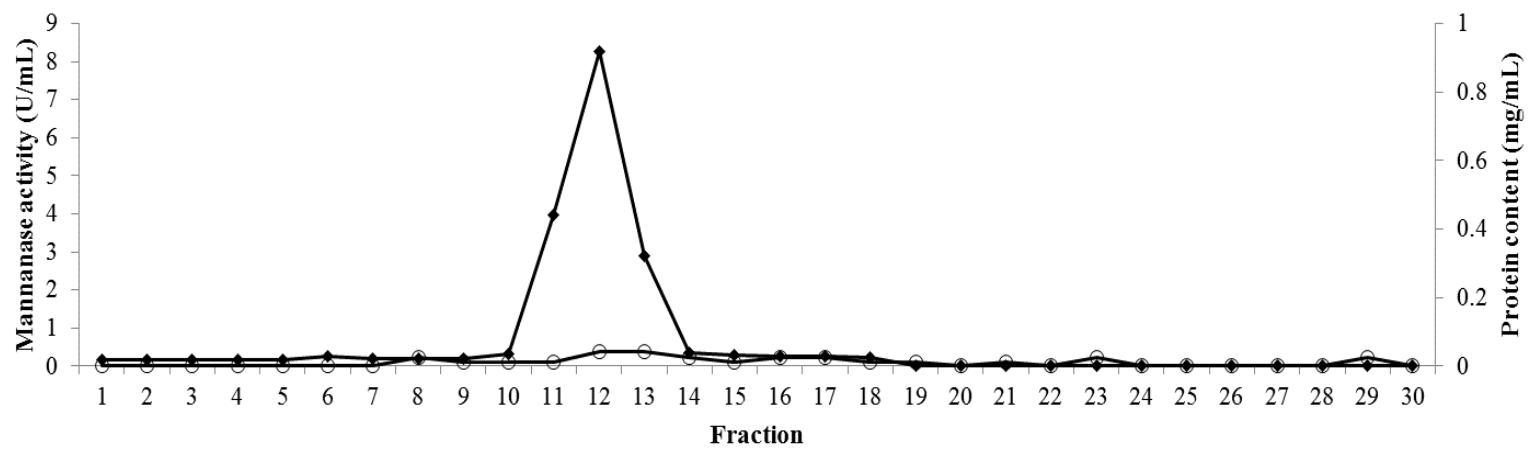

$\rightarrow$ Mannanase activity $\rightarrow$ Protein content

Figure 2: Purification of $\beta$-mannanase using Q-sepharose fast flow column with $50 \mathrm{mM}$ citric acid-trisodium citrate buffer (pH 5.0) containing $0.8 \mathrm{M} \mathrm{NaCl}$. 


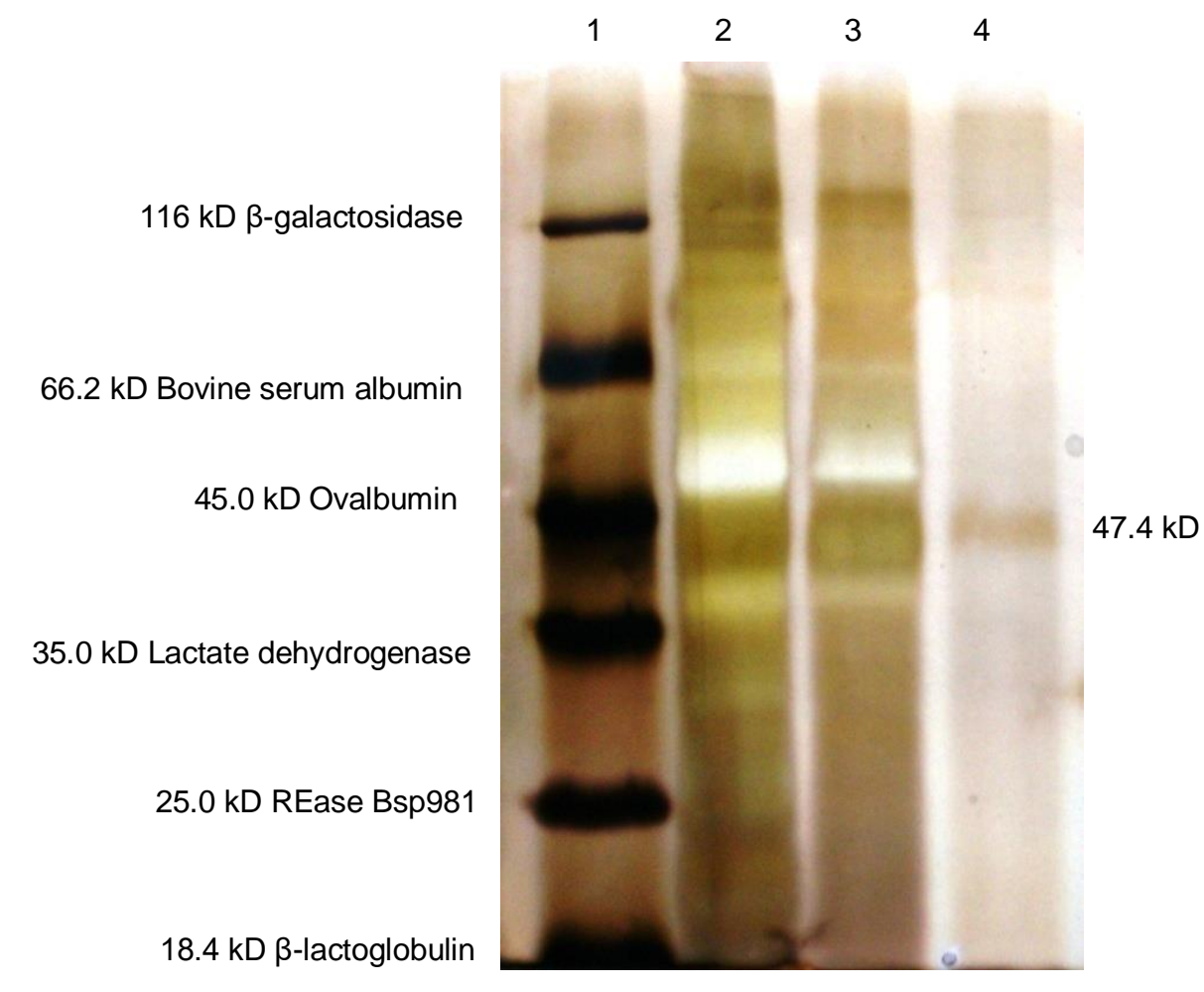

Figure 3: SDS-PAGE (12.5\%) of purified $\beta$-mannanase from A. niger USM F4. Lane 1: low molecular protein standard, lane 2: crude culture filtrate, lane 3: Superdex 75 column sample and lane 4: purified sample from Q-sepharose fast flow column.

The optimum $\mathrm{pH}$ condition for the purified $A$. niger $\beta$ mannanase to degrade the LBG was at $\mathrm{pH} 4.0(50 \mathrm{mM}$ citric acid-trisodium citrate buffer) (Figure 4). The relative activity was $93 \%$ at $\mathrm{pH} 3.0$ and the value gradually increased to its peak at $100 \%$ at $\mathrm{pH}$ 4.0. The activity decreased from pH 5.0 onwards. During the stability test, purified $\beta$-mannanase showed a remarkable endurance towards $\mathrm{pH} 3.0$ to 9.0 thresholds until $180 \mathrm{~min}$. A $30 \mathrm{~min}$ half-life of the residual activity was discovered at $\mathrm{pH} 10.0$ (Figure 5). According to the graph, the enzyme showed higher stability at $\mathrm{pH} 4.0$ than $\mathrm{pH} 5.0$ and 6.0.

The purified fungal $\beta$-mannanase is known to have a tendency on the acidic to neutral $\mathrm{pH}$ condition. It has been reported that the enzyme secreted from Aspergillus species, particularly $A$. niger, $A$. fumigatus, $A$. terreus and $A$. oryzae, are more stable at $\mathrm{pH}$ conditions of 3.5 to 7.0 (Ademark et al., 1998; El-Refai et al., 2014; Soni et al., 2016). In general, the purified fungal enzymes are well-adapted to a broad range of $\mathrm{pH}$ values viz. $\mathrm{pH} 3.0$ to 8.0 (Mudau and Setati, 2008; Naganagouda et al., 2009; Soni et al., 2016). However, the current pH stability was 1.0 unit higher than the above-mentioned reports, suggesting that the purified $\beta$-mannanase from $A$. niger USM F4 was still active in alkaline conditions.
Temperature is another de facto aspect that influenced the catalytic activity of proteins and both physical factors ( $\mathrm{pH}$ and temperature) in determining the application of proteins in industrial settings. In this study, the relative activity of the purified $\beta$-mannanase started with $89 \%$ at $50^{\circ} \mathrm{C}$ and optimally active $(100 \%)$ at $60^{\circ} \mathrm{C}$ (Figure 6). The activity exhibited a declining trend at $70{ }^{\circ} \mathrm{C}(97 \%)$ and 80 ${ }^{\circ} \mathrm{C}(92 \%)$. At temperatures of $50{ }^{\circ} \mathrm{C}$ to $70{ }^{\circ} \mathrm{C}$, the enzyme activities were stable up to $180 \mathrm{~min}$. However, at $80^{\circ} \mathrm{C}$, there was a $50 \%$ shortfall detected right after 30 min of the thermal exposure (Figure 7).

In term of characterisation of temperature, the result was aligned to Wu et al. (2011), Soni et al. (2016) and Karahalil et al. (2019). They recorded $60^{\circ} \mathrm{C}$ to $70{ }^{\circ} \mathrm{C}$ as optimum temperature ranges for mannan degradation by the genus Aspergillus $\beta$-mannanase. Adesina et al. (2013) contrarily evident the $\beta$-mannanase required a moderate temperature of $30^{\circ} \mathrm{C}$ to trigger and maximise the process. In terms of thermal stability, the recent experiment indicated $\beta$-mannanase from $A$. niger could endure high temperature up to $70^{\circ} \mathrm{C}$ for $180 \mathrm{~min}$. The result was better than previously reported by $\mathrm{Wu}$ et al. (2011) and Adesina et al. (2013) in which the enzyme stability only resists at temperatures of $60^{\circ} \mathrm{C}$ and below. 
Malays. J. Microbiol. Vol 16(5) 2020, pp. 396-406

DOI: http://dx.doi.org/10.21161/mjm. 200719

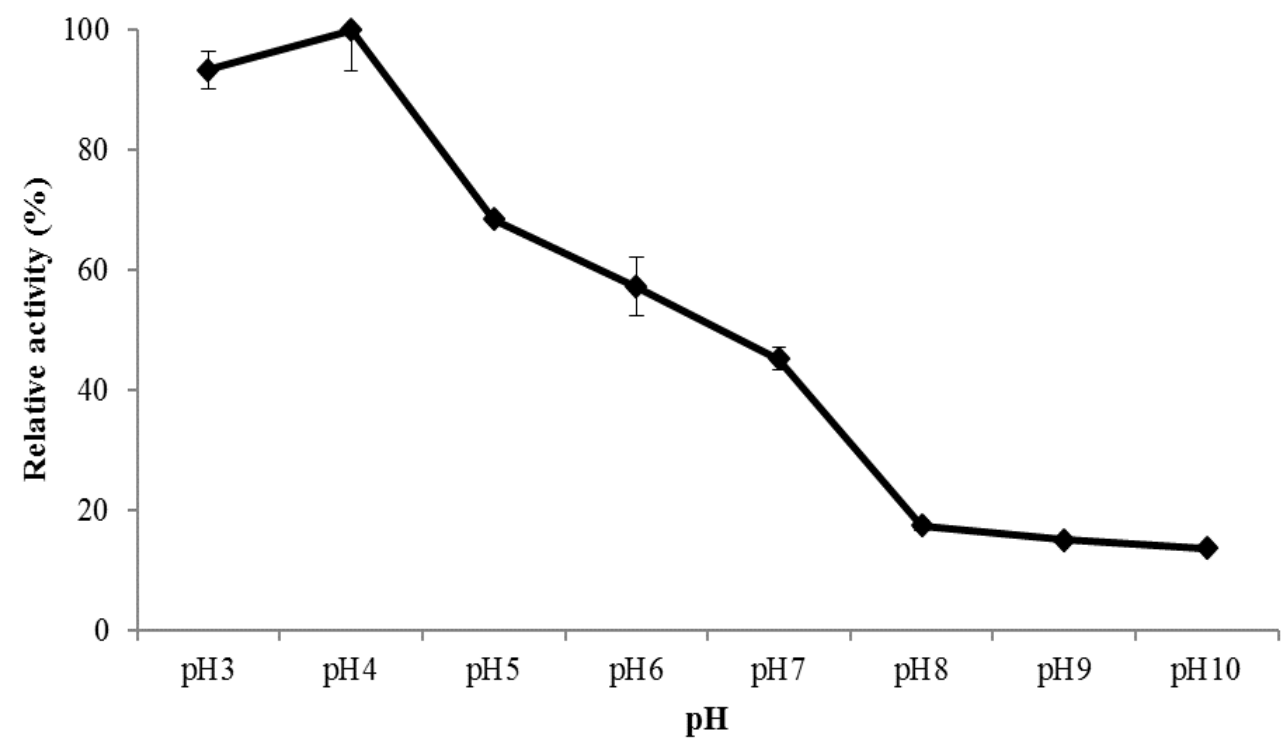

Figure 4: Influence of $\mathrm{pH}$ on the activity of $A$. niger $\beta$-mannanase. Conditions: the enzyme was blended with $0.5 \%$ (w/v) LBG in $50 \mathrm{mM}$ citric acid-trisodium citrate buffer, phosphate buffer, Tris- $\mathrm{HCl}$ buffer and glycine- $\mathrm{NaOH}$ buffer, $60{ }^{\circ} \mathrm{C}$.

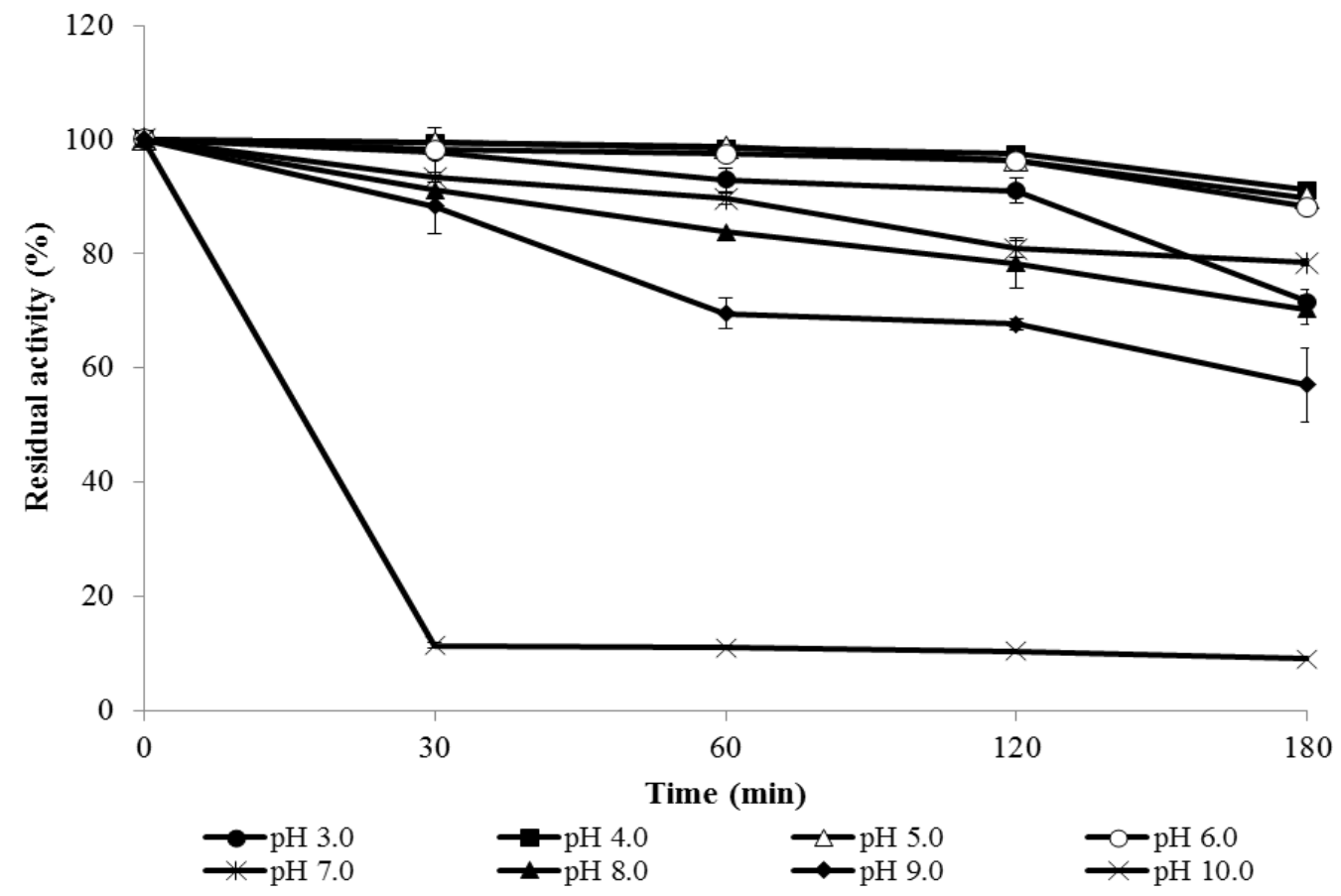

Figure 5: Stability of purified $\beta$-mannanase from $A$. niger USM F4 at various pHs. Conditions: the enzyme was preincubated without LBG in $50 \mathrm{mM}$ citric acid-trisodium citrate buffer $(\mathrm{pH} 3.0-5.0)$, phosphate buffer $(\mathrm{pH} 6.0-7.0)$, Tris- $\mathrm{HCl}$ buffer ( $\mathrm{pH}$ 8.0-9.0) and glycine- $\mathrm{NaOH}$ buffer $(\mathrm{pH} 10.0)$ and the activity was determined using $0.5 \%(\mathrm{w} / \mathrm{v})$ LBG in $50 \mathrm{mM}$ citric acid-trisodium citrate buffer at $60^{\circ} \mathrm{C}$. 


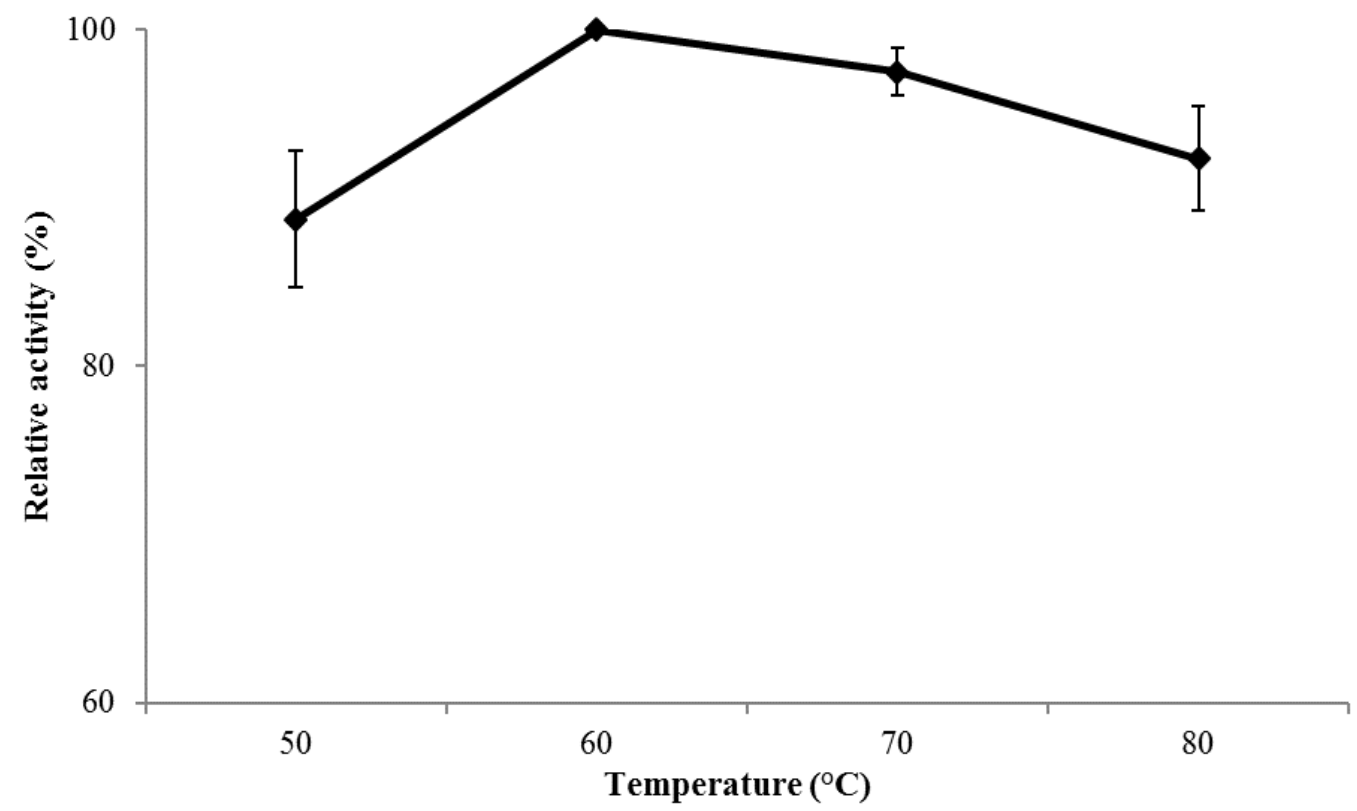

Figure 6: Influence of temperature on the activity of purified $\beta$-mannanase from $A$. niger USM F4. Conditions: the enzyme was mixed with $0.5 \%(\mathrm{w} / \mathrm{v})$ LBG in $50 \mathrm{mM}$ citric acid-trisodium citrate buffer $(\mathrm{pH} 4.0)$ and incubated at $50{ }^{\circ} \mathrm{C}$ to $80^{\circ} \mathrm{C}$.

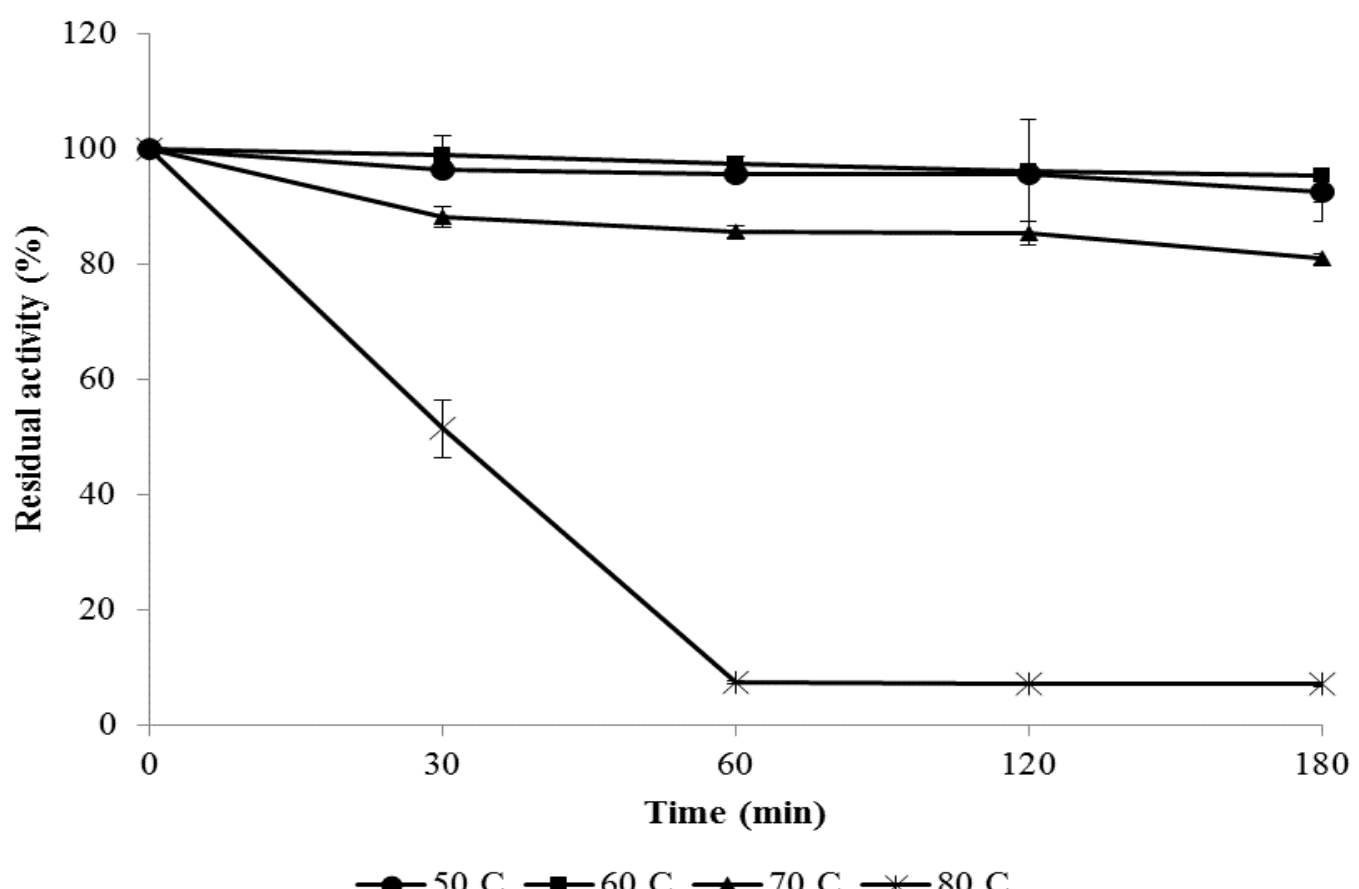

Figure 7: The thermal stability of purified $\beta$-mannanase at different temperatures. Conditions: purified enzyme was preincubated without substrate in $50 \mathrm{mM}$ citric acid-trisodium citrate buffer $(\mathrm{pH} 4.0)$ at temperatures of $50{ }^{\circ} \mathrm{C}$ to $80^{\circ} \mathrm{C}$. The assay was estimated using $0.5 \%(\mathrm{w} / \mathrm{v}) \mathrm{LBG}$ in $50 \mathrm{mM}$ citric acid-trisodium citrate buffer at $60^{\circ} \mathrm{C}$. 
The influence of several substances including organic compounds, metal ions and chelating agents on purified $\beta$-mannanase activity is depicted in Table 2. All substances inhibited the enzyme activity, with SDS pronounced as the strongest inhibitor at $1.0 \mathrm{mM}$. It led to a decrease in purified enzyme activity to $28.16 \pm 0.05 \%$. Cupric ion $\left(\mathrm{Cu}^{2+}\right)$ also exhibited a strong $\beta$-mannanase inhibitor after SDS, resulting in $49.51 \pm 0.09 \%$ of residual activity. SDS was recognised as an inhibitor for bacterial mannanase especially Bacillus sp. The exposure of purified bacterial mannanase and SDS at $60^{\circ} \mathrm{C}$ ended up with the activity reduction (Yoon et al., 2008). It is worth to mention the inhibitory effect of SDS on another hemicellulose such as Trichoderma inhamatum xylanase where its activity for type- 1 and type-2 enzymes was demolished in $10 \mathrm{mM}$ concentration (Silva et al., 2015). In general, the increase in SDS concentration has caused a decrease to the enzyme activity. The incident indicates that the SDS may interrupt the enzyme activity by invading its hydrophobic part and modified the three dimensional structures of the enzyme protein.

Table 2: The effect of chemical substances on purified $\beta$ mannanase activity.

\begin{tabular}{lc}
\hline Substance & Relative activity ${ }^{\mathrm{a}}(\%)$ \\
\hline Control & 100.00 \\
$\mathrm{SrCl}_{2}$ & $62.06 \pm 0.12$ \\
$\mathrm{ZnCl}_{2}$ & $57.04 \pm 0.11$ \\
$\mathrm{FeCl}_{3}$ & $54.95 \pm 0.10$ \\
$\mathrm{ZnSO}_{4}$ & $54.11 \pm 0.10$ \\
$\mathrm{CuSO}_{4}$ & $49.51 \pm 0.09$ \\
$\mathrm{CaCl}_{2}$ & $54.11 \pm 0.10$ \\
$\mathrm{MnCl}_{2}$ & $72.52 \pm 0.14$ \\
$\mathrm{AlCl}_{3}$ & $66.66 \pm 0.12$ \\
$\mathrm{NaCl}$ & $67.92 \pm 0.13$ \\
$\mathrm{KCl}$ & $69.59 \pm 0.13$ \\
$\mathrm{MgCl}$ & \\
EDTA & $58.71 \pm 0.11$ \\
$2-m e r c a p t o e t h a n o l$ & $56.20 \pm 0.10$ \\
SDS & $67.08 \pm 0.12$ \\
\hline
\end{tabular}

aThe experiment was done in triplicate in separate occasions and data was expressed as in mean \pm standard deviation.

The metal ions could connect with proteins via multiple networks linked to the amine or carboxylic acid group. According to Naganagouda et al. (2009), $\mathrm{Cu}^{2+}$ was among the top four inhibitors, besides mercury ions $\left(\mathrm{Hg}^{+}\right)$, silver ions $\left(\mathrm{Ag}^{+}\right)$, and $\mathrm{N}$-bromosuccinimide (NBS). To date, information on the influence of divalent ions on mannanase and its catalytic site is scarcely researched and poorly explained. The ions occurrence may probably be associated with redox reaction on the amino acids which indirectly contributed to the enzyme activity fluctuation (Tejirian and $\mathrm{Xu}, 2010$ ). The inhibition may also associate with the ionic charge and radius size of the enzymes. Amino acids have more intensive affinity on smaller radius sizes than the large sizes. Usually, the attachment between small radius sizes and amino acids cause numerous damages of the catalytic site (Zeng et al., 2014).

As reported by Naganagouda et al. (2009), Soni et al. (2016) and Karahalil et al. (2019), purified $\beta$-mannanase has a higher affinity towards LBG, a mannan polysaccharide containing-1,4-mannosidic linkages. The filamentous fungus has actively degraded the LBG and synthesised $100 \pm 0.50 \%$ enzyme activity (Table 3 ). According to the kinetic study of LBG, the $\mathrm{K}_{\mathrm{m}}$ and $\mathrm{V}_{\max }$ values were evidenced to be $0.20 \mathrm{mg} / \mathrm{mL}$ and $9.82 \mathrm{U} / \mathrm{mL}$, respectively. The assayed activities produced from other substrates were $17.00 \pm 0.22 \%$ (carboxymethyl cellulose, $\mathrm{CMC}$ ), $16.59 \pm 0.17 \%$ (soluble starch), $16.17 \pm 0.22 \%$ (xylan from oat spelt) and $15.61 \pm 0.03 \%$ ( $\alpha$-cellulose). The result was in line with that of $\beta$-mannanase produced from A. niger (Naganagouda et al., 2009), A. terreus (Soni et al., 2016) and $A$. fumigatus (Karahalil et al., 2019). The presence of different sugar units such as glucose, xylose and amylose may construct a steric interference to the accessibility of $A$. niger $\beta$-mannanase on CMC, soluble starch, xylan from oat spelt and $\alpha$-cellulose. The mechanism concerning mannan-degrading enzymes capacity on LBG and other heterogeneous substrates, mainly in selecting the mannose or glucose at distal subsites, is remained unclear (Tailford et al., 2009). Thus far, the majority of fungal mannanase with glycoside hydrolase $(\mathrm{GH})$ families 5 and 26 have a greater affinity towards glucomannan LBG (Xia et al., 2016).

Table 3: Substrate specificities of purified $\beta$-mannanase assayed at $60^{\circ} \mathrm{C}, \mathrm{pH} 4.0$.

\begin{tabular}{lc}
\hline Substrate type & Relative activity $^{\mathrm{a}}(\%)$ \\
\hline LBG & $100.00 \pm 0.50$ \\
Xylan from oat spelt & $16.17 \pm 0.22$ \\
CMC & $17.00 \pm 0.22$ \\
a-cellulose & $15.61 \pm 0.03$ \\
Soluble starch & $16.59 \pm 0.17$
\end{tabular}

aThe experiment was done in triplicate in separate occasions and data was expressed in mean \pm standard deviation.

We have done a comparison to evaluate the enzyme affinity on LBG in Table 4. In general, enzyme with low $\mathrm{K}_{\mathrm{m}}$ has a high affinity for its substrate and commonly necessitates a lower concentration of substrate to attain $\mathrm{V}_{\text {max. }}$. From the table, the $\mathrm{K}_{\mathrm{m}}$ generated by both $A$. niger $\beta$ mannanase [USM F4 $=0.20 \mathrm{mg} / \mathrm{mL}$, Naganagouda et al. (2009) $=0.11 \mathrm{mg} / \mathrm{mL}$ ] were lower than $A$. terreus [Soni et al. $(2016)=5.9 \mathrm{mg} / \mathrm{mL}$ ] and $A$. fumigatus [Karahalil et al. $(2019)=10.48 \mathrm{mg} / \mathrm{mL}$ ]. The application of LineweaverBurk plot or double reciprocal plot in evaluating the $\mathrm{K}_{\mathrm{m}}$ and $\mathrm{V}_{\max }$ values has statistical inherent limitation. Our linear plot was more enunciated at low substrate concentration (graph not shown) and caused the occurrence of imbalance weighting of errors. This event has generated long lever arm effect which may influence the estimation of $\mathrm{K}_{\mathrm{m}}$ value due to extrapolation (Johnson, 2013). 
Table 4: The affinity of $\beta$-mannanase produced from different filamentous fungi on natural LBG.

\begin{tabular}{lccc}
\hline Fungus & $\begin{array}{c}\mathrm{K}_{\mathrm{m}} \\
(\mathrm{mg} / \mathrm{mL})\end{array}$ & $\begin{array}{c}\mathrm{V}_{\max } \\
(\mathrm{U} / \mathrm{mL})\end{array}$ & References \\
\hline $\begin{array}{l}\text { A. niger } \\
\text { USM F4 }\end{array}$ & 0.20 & 9.82 & - \\
A. niger & 0.11 & 14.13 & $\begin{array}{c}\text { Naganagouda } \\
\text { et al. (2009) }\end{array}$ \\
$\begin{array}{l}\text { A. terreus } \\
\text { A. fumigatus }\end{array}$ & 5.9 & 39.42 & $\begin{array}{c}\text { Soni et al. (2016) } \\
\text { Karahalil et al. } \\
(2019)\end{array}$ \\
\hline
\end{tabular}

\section{CONCLUSION}

As a summary, the purified $\beta$-mannanase from $A$. niger USM F4 has a molecular mass of $\sim 47.4 \mathrm{kDa}$ and reached its maximum activity under physical conditions of $\mathrm{pH} 4.0$ and a temperature of $60^{\circ} \mathrm{C}$. These conditions were similar to the crude enzyme assay conditions. The enzyme was stable over an extensive range of $\mathrm{pH}$ values and temperatures, required no extra chemical substances to manifold the activity and had an affinity on the natural mannan source (LBG) that inexpensively available. Besides, $A$. niger does not produced toxin and generally recognised as safe (GRAS). These characteristics are appropriately relevant for application in the industrial league.

\section{REFERENCES}

Abd-Aziz, S., Ab-Razak, N. N., Musa, M. H. and Hassan, M. A. (2009). Production of mannandegrading enzymes from Asperillus niger and Sclerotium rolfsii using palm kernel cake as carbon source. Research Journal of Environmental Sciences 3(2), 251-256.

Ademark, P., Varga, A., Medve, J., Harjunpaa, V., Drakenberg, T., Tjerneld, F. and Stalbrand, H. (1998). Softwood hemicellulose-degrading enzymes from Aspergillus niger: Purification and properties of a $\beta$-mannanase. Journal of Biotechnology 63, 199-210.

Adesina, F. C., Oluboyede, O. A. and Onilude, A. A. (2013). Production, purification and characterization of a $\beta$-mannanase by Aspergillus niger through solid state fermentation (SSF) of Gmelina arborea shavings. African Journal of Microbiology Research 7(4), 282-289.

Benech R. O., Li, X., Patton, D., Powlowski, J., Storms, R., Bourbonnais, R., Paice, M. and Tsang, A. (2007). Recombinant expression characterization, and pulp prebleaching property of a Phanerochaete chrysosporium endo- $\beta 1,4$ mannanase. Enzyme and Microbial Technology 41(6-7), 740-747.

Blibech, M., Ghorbel, R. E., Chaari, F., Dammak, I., Bhiri, F., Neifar, M. and Chaabouni, S. E. (2011).
Improved mannanase production from Penicillium occitanis by fed-batch fermentation using acacia seeds. ISRN Microbiology 2011, Article ID 938347.

Bollag, D. M., Rozycki, M. D. and Edelstein, S. J. (1996). Protein Methods. 2nd Edn. Wiley-Liss, Inc, New York. pp. 83-103.

Carrington, C. M. S., Vendrell, M. and DomíguezPuigjaner, E. (2002). Characterisation of an endo$(1,4)-\beta$-mannanase (LeMAN4) expressed in ripening tomato fruit. Plant Science 163, 599-606.

Cheng, L., Duan, S., Feng, X., Zheng, K., Yang, Q. and Liu, Z. (2016). Purification and characterization of a thermostable $\beta$-Mannanase from Bacillus subtilis BE91: Potential application in inflammatory diseases. BioMed Research International 2016, Article ID 6380147.

Costa, J. A. V., Treichel, H., Kumar, V. and Pandey, A. (2018). Advances in solid-state fermentation. In: Current Development in Biotechnology and Bioengineering. Pandey, A., Larroche, C. H. and Soccol, C. (eds.). Elsevier B.V., Amsterdam, Netherlands. pp. 1-17.

El-Sharouny, E. E., El-Toukhy, N. M. K., El-Srsy, N. A. and El-Gayar, A. A. E-A. (2015). Optimization and purification of mannanase produced by an alkaliphilicthermotolerant Bacillus cereus N1 isolated from Bani Salama Lake in Wadi El-Natron. Biotechnology, Bioechnological Equipment 29(2), 315-323.

El-Refai, M. A., Khattab, O. H., Ismail, S. A., Hashem, A. M., Abo-Elnasr, A. A. and Nour, S. A. (2014). Improved mannanase production from Penicillium humicola and application for hydrolysis property. Egyptian Pharmaceutical Journal 13(2), 160-167.

Harnpicharnchai, P., Pinngoen, W., Teanngam, W., Sornlake, W., Sae-Tang, K., Manitchotpisit, P. and Tanapongpipat, S. (2016). Production of high activity Aspergillus niger BCC4525 $\beta$-mannanase in Pichia pastoris and its application for mannooligosaccharides production from biomass hydrolysis. Bioscience, Biotechnology, and Biochemistry 80(12), 2298-2305.

Illuyemi, F. B, Hanafi, M. M., Radziah, $O$. and Kamarudin, M. S. (2006). Fungal solid state culture of palm kernel cake. Bioresource Technology 97, 477482

Johnson, K. A. (2013). A Century of Enzyme Kinetic Analysis, 1913 to 2013. FEBS Letters 587(17), 27532766.

Karahalil, E., Germec, M., Karaoglan, M., Yatmaz, E., Coban, H. B., Inan, M. and Turhan, I. (2019). Partial purification and characterization of a recombinant $\beta$ mannanase from Aspergillus fumigatus expressed in Aspergillus sojae grown on carob extract. Biomass Conversion and Biorefinery, 1-17.

Kim, D. Y., Ham, S. J., Lee, H. J., Cho, H. Y., Kim, J. H., Kim, Y.J ., Shin, D. H., Rhee, Y. H., Son, K. H. and Park, H. Y. (2011). Cloning and characterization of a modular GH5 $\beta$-1,4-mannanase with high specific activity from the fibrolytic bacterium Cellulosimicrobium sp. strain HY-13. Bioresources Technology 102, 9185-9192. 
Krishnaiah, D., Bono, A., Sarbatly, R. and Siti Fadhilah. (2012). Supercritical fluid extraction of palm kernel oil from palm kernel cake. American Journal of Food Technology 7(3), 168-172.

Laemmli, U. K. (1970). Cleavage of structural protein during the assembly of the head of bacteriophage T4. Nature 227, 680-685.

Lin, T. C. and Chen, C. (2004). Enhanced mannanase production by submerged culture of Aspergillus niger $\mathrm{NCH}-189$ using defatted copra based media. Process Biochemistry 39, 1103-1109.

Lineweaver, H. and Burk, D. (1934). The determination of enzyme dissociation constants. Journal of the American Chemical Society 56(3), 658-666.

Lowry, O. H., Rosebrough, N. J., Farr, A. L. and Randall, R. J. (1951). Protein measurement with Floin phenol reagent. Journal of Biological Chemistry 193, 265-275.

Luo, H., Wang, Y., Wang, H., Yang, J., Yang, Y., Huang, H., Yang, P., Bai, Y., Shi, P., Fan, Y. and Yao, B. (2009). A novel highly acidic $\beta$-mannanase from the acidophilic fungus Bispora sp. MEY-1: Gene cloning and overexpression in Pichia pastoris. Applied Microbiology and Biotechnology 82, 453-461.

Marini, A. M., Daud, M. J., Noraini, S. Jame'ah, H. and Azahan E. A. E. (2005). Performance of locally isolated microorganism in degrading palm kernel cake (PKC) fibre and improving the nutritional value of fermented PKC. Journal of Tropical Agriculture and Food Science 33, 311-319.

MPOB (2019). Production of palm kernel cake for the month of December. MPOB: http://bepi.mpob.gov.my/index.php/en/statistics/produc tion/186-production-2018/847-production-of-palmkernel-cake-2018.html [Retrieved on 4 November 2019]

Mudau, M. M. and Setati, M. E. (2008). Partial purification and characterization of endo- $\beta 1,4$ mannanases from Scopularipsis candida strains isolated from solar salterns. African Journal of Biotechnology 7(13), 2279- 2285.

Naganagouda, K., Salimath, P. V. and Mulimani, V. H. (2009). Purification and characterization of endo- $\beta-1,4$ mannanase from Aspergillus niger gr for application in food processing industry. Journal of Microbiology and Biotechnology 19(10), 1184-1190.

Nurhayati, Hartutik, Osfar Sjofjan and Widodo, E. (2018). Production of mannan oligosaccharides (MOS) extracted from fermented palm kernel cake and cassava by-product mixture and its efficacy as prebiotic. Livestock Research for Rural Development 30, article

179. http://www.Irrd.org//rrd30/10/eko30179.html [Retrieved on 4 November 2019]

Puchart, V., Vršanská, M., Svoboda, P., Pohl, J., Ögel, Z. B. and Biely, P. (2004). Purification and characterization of two forms of endo- $\beta-1,4-$ mannanase from a thermotolerant fungus, Aspergillus fumigatus IMI 385708 (formerly Thermomyces lanuginosus IMI 158749). Biochimica et Biophysica Acta 1674, 239-250.

Regalado, C., Garcia-Almendarez, B. E., VenegasBarrera, L. M., Tellez-Jurado, A., RodriguezSerrano, G., Huerta-Ochoa, S. and Whitaker, J. R., (2000). Production, partial purification and properties of $\beta$-mannanases obtained by solid substrate fermentation of spent soluble coffee wastes and copra paste using Aspergillus oryzae and Aspergillus niger. Journal of the Science of Food and Agriculture 80, 1343-1350.

Silva, L. A. O., Terrasan, C. R. F. and Carmona, E. C. (2015). Purification and characterization of xylanases from Trichoderma inhamatum. Electronic Journal of Biotechnology 8, 307-313.

Soni, H., Rawat, H. K., Pletschke, B. I. and Kango, N. (2016). Purification and characterization of $\beta$ mannanase from Aspergillus terreus and its applicability in depolymerization of mannans and saccharification of lignocellulosic biomass. 3 Biotech 6(2), 136.

Srivastava, P. K. and Kapoor, M. (2013). Cost effective endo-mannanase from Bacillus sp. CFR1601 and its application in generation of oligosaccharides from guar gum and as detergen additive. Preparative Biochemistry and Biotechnology 44(4), 392-417.

Syarifah, A. R. (2010). Pengoptimuman, penulenan dan pencirian enzim mannanase daripada Aspergillus niger USM F4 melalui pemfermentasian substrat pepejal (SSF) dengan menggunakan isirong kelapa sawit sebagai substrat. M.Sc. Thesis. Universiti Sains Malaysia, Malaysia.

Syarifah, A. R, Darah, I and Ibrahim, C. O. (2012). Mannanase production by Aspergillus niger USM F4 via solid substrate fermentation in a shallow tray using palm kernel cake as a substrate. Malaysian Journal of Microbiology 8(4), 273-279.

Tailford, L. E., Ducros, A. M. A., Flint, J. E., Roberts, S. M., Morland, C., Zechel, D. L., Smith, N., Bjørnad, M. E., Borchert, T. V., Wilson, K. S., Davies, G. J. and Gilbert, H. J. (2009). Understanding how diverse $\beta$-mannanases recognize heterogeneous substrates. Biochemistry 48(29), 7009-7018.

Takeshita, N. (2016). Coordinated process of polarized growth in filamentous fungi. Bioscience, Biotechnology and Biochemistry 80(9), 1693-1699.

Tejirian, A. and $\mathrm{Xu}, \mathrm{F}$. (2010). Inhibition of cellulasecatalyzed lignocellulosic hydrolysis by iron and oxidative metal ions and complexes. Applied and Environmental Microbiology 76, 7673-7682.

Tewoldebrhan, T. A., Appuhamy, J. A. D. R. N., Lee, J. J., Niu, M., Seo, S., Jeong, S. and Kebreab, E. (2017). Exogenous $\beta$-mannanase improves feed conversion efficiency and reduces somatic cell count in dairy cattle. Journal of Dairy Science 100, 244-252.

Wu, M., Tang, C., Li, J., Zhang, H. and Guo, J. (2011). Bimutation breeding of Aspergillus niger strain of $\beta$ mannanase production by solid state fermentation. Carbohydrate Research 346, 2149-2155. 
Malays. J. Microbiol. Vol 16(5) 2020, pp. 396-406

DOI: http://dx.doi.org/10.21161/mjm. 200719

Xia, W., Lu, H., Cui, M., Bai, Y., Qian, L., Shi, P., Luo, H. and Yao, B. (2016). A novel glycosidase hydrolase family 113 endo- $\beta-1,4,-$ mannanase from Alicylobacillus sp. strain A4 and insight into the substrate recognition and catalytic mechanism of this family. Applied and Environmental Microbiology 82(9), 2718-2727.

Yoon, K. H., Chung, S. and Lim, B. L. (2008). Characterization of Bacillus subtilis WL-3 mannanase from recombinant Escherichia coli. Journal of Microbiology 46(3), 344-349.

Zakaria, M. M., Yamamoto, S. and Yagi, T., (1998). Purification and characterization of an endo-1,4- $\beta-D-$ mannanase from Bacillus subtilis $\mathrm{KU}-1$. FEMS Microbiology Letters 158, 25-31.

Zeng, J., Gao, X., Dai, Z., Tang, B. and Tang, X. F. (2014). Effects of metal ions on stability and activity of hyperthermophilic pyrolysin and further stabilization of this enzyme by modification of a $\mathrm{Ca}^{2+}$-binding site. Applied and Environmental Microbiology 80, 27632772. 